\title{
Role of Cytokines in the Formation and Downregulation of Hepatic Circumoval Granulomas and Hepatic Fibrosis in Schistosoma mansoni-Infected Mice
}

\author{
Allen W Cheever ${ }^{+}$, Dragana Jankovic, George S Yap, Marika C Kullberg, \\ Alan Sher, Thomas A Wynn
}

Immunobiology Section, Laboratory of Parasitic Diseases, NIAID, NIH, Bethesda, MD 20892-0425 \& Biomedical Research Institute, Rockville, MD, USA

\begin{abstract}
Schistosoma mansoni infections are associated with a strong Th2 cytokine response. Treatment of mice with IL-12 or anti-IL-2 or anti-IL-4 before i.v. injection of eggs increased IFN-gproduction and downregulated Th2 responses and pulmonary granuloma size. Conversely, anti-IFN-gantibody treatment increased Th2 responses and granuloma size. Similar manipulation produced less dramatic results in infected mice. However, sensitization of mice with eggs $+I L-12$ before infection augmented the Th1 response and decreased Th2 cytokines, granuloma size and fibrosis. Antisera to IFN-g TNF-a or IL-12 during IL-12-egg immunization partly restored granuloma size and fibrosis following infection.

Variations in the size of granulomas in acute ( 8 week) infections may be influenced primarily by the number and state of activation of T cells. In chronic (12-16 week) infections immunologic downmodulation proceeded normally in mice without functional CD8+ cells and in IFN-gKO mice but not in B cell KO (mMT) mice or in mice deficient in FcR expression in spite of the fact that these mice downregulated their $T$ cell and cytokine responses. It is evident that the participation of cytokines in granuloma formation and regulation is complicated and that the mechanisms controlling both these phenomena are likely to involve both $T$ cells and antibody/FcR interactions.
\end{abstract}

Key words: schistosomiasis - granulomas - cytokines - immunoregulation - hepatic fibrosis - type 2 delayed hypersensitivity

The granulomas around Schistosoma mansoni eggs cause most of the pathology of $S$. mansoni infections in immunologically competent animals. CD4+ lymphocytes are central in orchestrating the formation and growth of the granulomas and secretion of cytokines, and the resulting cascade of adhesins, chemokines etc. direct the cellular interactions which take place around the schistosome egg (Weinstock 1992, Chensue et al. 1994a, Jankovic \& Sher 1996). Chesney et al. (1998) have recently suggested that circulating fibrocytes entering the granulomas may be important in attracting CD4+ lymphocytes.

Most evidence concerning the role of cytokines in circumoval granuloma formation has been obtained either from infected mice or from mice given intravenous eggs or antigen on beads with subsequent examination of the granulomas formed in the lungs (the "lung model"). The lung model ob-

\footnotetext{
${ }^{+}$Corresponding author. Fax: $+301-770.4756$ or 301402.0890. E-mail: achever@atlas.niaid.nih.gov

Received 4 May 1998

Accepted 31 August 1998
}

viously provides excellent opportunities to examine immune responses initiated with a synchronous pulse of antigen (Chensue et al. 1992, Wynn et al. 1993), but the immune response and immunopathology in the lung model sometimes do not coincide with those seen in infected mice.

Th1-vs Th2-like responses affect granuloma formation and schistosomal hepatic fibrosis - Th1 responses are accompanied by secretion of IFN-g and IL-2 and are traditionally associated with delayed type hypersensitivity (DTH) reactions while Th2 responses are accompanied by the secretion of IL-4 (necessary for IgE production), IL-5 (vital for eosinopoiesis) and IL-10. Schistosome infections are associated with high levels of serum $\operatorname{IgE}$ and the presence of blood and tissue eosinophilia which indicate a predominantly Th2-type reaction. Several recent reviews deal with the relation of cytokines to pathology in schistosome infections (Lukacs \& Boros 1993, Wynn \& Cheever 1995, Cheever \& Yap 1997, Cheever et al. 1998).

Treatment of mice with cytokines and antibodies to cytokines generally supports the importance of Th2-type reactions for the formation and maintenance of large granulomas (Tables I, II). Antibodies neutralizing IL-2 (thus inhibiting expansion 
TABLE I

Effect on granuloma size of cytokine and anticytokine treatment of mice given intravenous Schistosoma mansoni eggs

\begin{tabular}{lll}
\hline Treatment & Effect $^{a}$ & References \\
\hline IFN-g & - & Lukacs \& Boros 1993 \\
Anti-IFN-g & + & Lukacs \& Boros 1993, Chensue et al. 1994, 1995, \\
& & Wynn et al. 1994 \\
IL-4 & + & Chensue et al. 1992 \\
Anti-IL-4 & --- & Chensue et al 1992, 1994, Wynn et al. 1994 \\
IL-12 & - & Wynn et al. 1994 \\
IL-12+ egg vaccination & --- & Wynn et al. 1994 \\
Anti-IL-12 & + & Wynn et al. 1994 \\
IL-10 & - & Flores-Villanueva et al. 1996a \\
Anti-IL-10 & 0 & Chensue et al. 1994, Wynn et al. 1994 \\
\hline
\end{tabular}

$a$ : indicates a decrease; $+:$ an increase, and 0 : no change.

TABLE II

Effect on granuloma size and hepatic fibrosis of cytokine and anticytokine treatment of Schistosoma mansoni infected mice

\begin{tabular}{llll}
\hline Treatment & $\begin{array}{l}\text { Effect- } \\
\text { size }^{a}\end{array}$ & $\begin{array}{l}\text { Effect- } \\
\text { fibrosis }\end{array}$ & References \\
\hline IFN-g during infection & -- & -- & Czaja et al. 1989 \\
Anti-IFN-gduring infection & 0 & 0 & Sher et al. 1990, Cheever et al. 1992 \\
IL-4 during infection & + & + & Yamashita \& Boros 1992 \\
Anti-IL-4 during infection & - & --- & Yamashita \& Boros 1992, Cheever et al. 1994 \\
IL-12 starting at 4-5 weeks & \pm & \pm & Oswald et al. unpublished \\
IL-12 + egg vaccination & --- & -- & Wynn et al. 1995 \\
before infection & - & $?$ & Flores-Villanueva et al. 1996 \\
L-10 \& IL-10 Fc during infection & - & &
\end{tabular}

$a$ : indicates a decrease; $+:$ an increase, and 0 : no change.

of CD4+ lymphocytes) or IL-4 (blocking differentiation and expansion of Th2 cells) diminished granuloma size and hepatic fibrosis (Cheever et al. 1992, 1994).

Immunization of mice with schistosome eggs together with IL-12 led to an augmented Th1-type response, a diminished $\mathrm{Th} 2$ response and a decrease in granuloma size and hepatic fibrosis when the mice were later infected (Wynn et al. 1995). Treatment during immunization with anti-IL-12, antiIFN-g or anti-TNF-a largely abrogated the effect of IL-12-egg immunization when mice were later infected (Wynn et al., unpublished).

We have seen at least two exceptions to the phenomenon of decreased immunopathology with an increase in Th1 response. S. mansoni-infected IL-10 KO mice demonstrated increased IFN-gresponses with markedly increased granuloma size (Wynn et al. 1998). Infected IL-4 KO mice on a BALB/c background also showed very high IFN-g levels and greatly enlarged granulomas
(Jankovic et al. unpublished). In both instances, total hepatic fibrosis was, surprisingly, unaffected. Overall, $S$. mansoni infections in various kinds of IL-4 KO mice elicit a bewildering diversity of responses (Table III). The genetic background of the mice, and perhaps local factors in various laboratories, profoundly affects the interaction of the murine host with the schistosome infection. This initially puzzling result opens new opportunities to determine the immunopathological consequences of the different approaches mice use in dealing with the infection.

Mice with severe combined immunodeficiency (scid mice) have a minimal reaction to S. mansoni eggs but when given exogenous tumor necrosis factor (TNF-a) infected scid mice formed substantial circumoval granulomas (Amiri et al. 1992). Treatment of S. mansoni-infected mice with polyclonal anti-TNF-a diminished the size of hepatic granulomas (Joseph \& Boros 1993). Monoclonal anti-TNF-a had little effect on granulomas 
TABLE III

Role of restriction of IL-4 on granuloma volume and hepatic fibrosis

\begin{tabular}{llll}
\hline Treatment & $\begin{array}{l}\text { Effect on } \\
\text { size }^{a}\end{array}$ & $\begin{array}{l}\text { Effect on } \\
\text { fibrosis }\end{array}$ & References \\
\hline $\begin{array}{l}\text { Anti-IL-4 monoclonal during infection } \\
\text { Anti-IL-4 polyclonal during infection }\end{array}$ & - & --- & Cheever et al. 1994 \\
IL-4 KO B6 x 129 & -- & $?$ & Yamashita \& Boros 1992 \\
IL-4 KO crossed to B6 (toxic death-TNF-a) & 0 & 0 & Pearce et al. 1996 \\
IL-4 KO germline B6 & -- & 0 & Rosa Brunet et al. 1997. \\
IL-4 KO crossed to BALB/c & ++++ & $?$ & Metwali et al. 1996 \\
\hline
\end{tabular}

$a$ : indicates a decrease; + : an increase; 0 : no change.

in the lung model (Chensue et al. 1994b) or infected mice (Cheever et al., unpublished). Mice lacking both p55 and p75 chains of the TNF-a receptor formed normal circumoval granulomas 8 weeks after infection (Yap et al. unpublished). The extent and mechanism of the participation of TNF-a need further clarification.

Are there different types/mechanisms of immunologic regulation in S. mansoni-infected mice? Downregulation of the immunologic responses of CD4+ T cells, mediated by CD8+ T cells, was long thought to be the mechanism of downmodulation of granulomatous responses to $S$. mansoni eggs (Chensue \& Boros 1979, Green \& Colley 1981). More recently B cells have been shown to be necessary for this downregulation through a process requiring functional $\mathrm{Fc}$ receptors in addition to modulation of the $\mathrm{T}$ cell response (Jankovic et al. 1998).

One may also ask, as discussed below, whether the mechanisms of downregulation are the same in acute and chronic infections and whether the mechanisms are the same in the liver as compared to other organs (Weinstock \& Boros 1981, Souza Vidal et al. 1993). The regulation of fibrosis in the liver may differ from the regulation of granuloma size (Olds et al. 1989, Phillips et al. 1996, Cheever 1997). In addition, the absence of regulatory idiotypes correlated with the development of pipestem portal fibrosis (a qualitative microscopic assessment) in mice but not with altered regulation of granuloma size (Henderson et al. 1993). Splenocytes of these mice were unresponsive to schistosome egg antigens (Bosshardt et al. 1997). Although total hepatic collagen was higher in mice with pipestem fibrosis, more eggs were present and collagen was not increased in relation to egg numbers (quantitative assessments) (Adewusi et al. 1996).

Immunologic downregulation of granuloma size in the livers of chronically-infected mice Downregulation of the size of $S$. mansoni-induced circumoval granulomas was first described in chronically-infected mice (Andrade \& Warren 1964) and downregulation has generally been studied comparing mice with infections of 8 weeks duration to those with infections of $>16$ weeks duration. Downregulation has generally been associated with the activity of CD8+ suppressor cells (Chensue \& Boros 1979, Green \& Colley 1981). However, mice in which CD8+ cell function was genetically deleted formed normal granulomas (Hernandez et al. 1997b, Yap et al. 1997) and several varieties of such mice [CD-8 knockout (KO) mice, $\beta-2$ microglobulin KO mice and TAP-1 KO mice] downregulated granuloma size normally and showed fibrosis equivalent to that in intact mice (Yap et al. 1997). IFN-gmight be expected to be a key mediator of downregulatory responses, but IFN-gKO mice also downregulated granuloma size normally (Yap et al. 1997).

Passive transfer of antibody from chronicallyinfected mice to immunologically intact mice at 6 weeks of infection did not result in downregulation of lesions at 8-weeks (Colley 1976). However, mice rendered deficient in B cells by anti-m antiserum (Cheever et al. 1985) and chronically-infected B cell ko mice (mMT mice, Jankovic et al. 1998) failed to downregulate granuloma size and showed increased hepatic fibrosis. T cell responses in $\mathrm{mMT}$ mice, measured as proliferation and by cytokine production, were downregulated as in the wild type-infected mice. In the mMT mice granuloma size was decreased by the passive transfer of serum from chronically infected mice (Jankovic et al. 1998). Antibody apparently acts via the Fc receptors on cells as KO mice (on a C57BL/6 background) deficient in FcR had abundant antibody but did not downregulate granuloma size (Jankovic et al. 1998). These findings are consistent with the reported effects of immune complexes on the formation of in vitro granulomas (Goes et al. 1991, Rezende et al 1997a,b).

Granulomas in FCeR1 KO mice (on a BALB/c 
background) were larger at 8 weeks than granulomas in wild type mice (Jankovic et al. 1997). This, and the very large granulomas seen at 8 weeks of infection in BALB/c IL-4 KO mice, suggest that $\mathrm{IgE}$, mast cells, non-B, non-T cells and basophils may be involved in regulating granuloma size in $\mathrm{BALB} / \mathrm{c}$ mice while in C57BL/6 mice other mechanisms might be more important. Chronic infections have not yet been examined in FceR1 KO mice.

Downregulation in chronically infected mice was partially or completely abrogated by treatment with IL-2 (Mathew et al. 1990), IL-4 (Yamashita \& Boros 1992) or TNF-a (Joseph \& Boros 1993) suggesting that all of these cytokines are involved in the downregulatory process.

Downmodulation of granuloma size in the liver may differ from regulation of granuloma size in the gut (Weinstock \& Boros 1981) or lungs (Souza Vidal et al. 1993) of infected mice and regulation of hepatic fibrosis frequently differs from that of hepatic granuloma size (Olds et al. 1989, Cheever 1997).

Immunologic regulation of granuloma size in acutely-infected mice - The presence of immune regulation during acute infection was first suggested by Hood and Boros (1980) who found that mice splenectomized 6 weeks after infection showed an increase in granuloma size 2 weeks later when compared to sham-operated mice, an effect attributed to the removal of CD8+ cells by splenectomy. Cimetidine or cyclophosphamide treatment of mice beginning at 6 weeks of infection also led to an increase in granuloma size (Weinstock \& Boros 1981, Weinstock et al. 1983) which was attributed to the removal of regulatory $\mathrm{T}$ cells. Increased granuloma size and hepatic fibrosis was noted by 8 weeks of infection in mMT B cell KO mice (Jankovic et al. 1998) although in another B cell KO mouse (JHD) granulomas were the same size as those in control mice (Hernandez et al. 1997a). Chronic infections were not examined in JHD mice. FcR KO mice also showed large granulomas 8 weeks after infection (Jankovic et al. 1998).

Stadecker (1992) has proposed that downregulation is caused by IL-10 mediated T cell anergy and he and his colleagues showed downmodulation of anti-egg immune response and granuloma size in acute infection by IL-10 (Villanueva et al. 1994, Flores-Villanueva et al. 1996). In agreement with this, Wynn et al. (1998) found very large granulomas at 8 weeks of infection in IL-10 KO mice, but these mice downregulated granuloma size in chronic infections suggesting that other mechanisms may be more important. Bosshardt et al. (1997) reported low IL-10 levels in chronically-infected mice which lacked regulatory idiotypes and developed pipestem fibrosis.

It seems that granuloma size in acute $S$. mansoni infections is determined primarily by $\mathrm{T}$ cell reactivity and is therefore sensitive to IL-10 (FloresVillanueva et al. 1996, Wynn et al. 1998), cimetidine and cyclophosphamide (Weinstock \& Boros 1981) while antibody has a minor effect (Jankovic et al. 1998). Downregulation of granuloma size in chronic infections requires antibody and downmodulated T cells (Jankovic et al. 1998).

In S. japonicum-infected mice early downregulation of granuloma size was predominantly $\mathrm{T}$ cell mediated while in chronic infections downregulation was almost exclusively via regulatory crossreactive idiotypes (Olds \& Stavitsky 1986, Kresina \& Olds 1986). Immunoregulatory idiotypes are also important in S. mansoni-infected mice (Montesano et al. 1997) but have not been reported to affect granuloma size, and T cell responses to $S$. mansoni egg antigen were virtually absent in mice lacking the regulatory idiotypes (Bosshardt et al. 1997).

Comparison of granulomas around injected eggs in the lung model with granulomas in infected mice - We were impressed with the dramatic effect of anti-IL-4 treatment on granulomas around eggs injected into the lungs compared to a slight effect on the size of hepatic granulomas in the same infected mice (Cheever et. al 1994, Eltoum et al. 1995). When a shunt was produced surgically to divert eggs laid by the worms to the lungs, the effect of anti-IL-4 on the granulomas was slight, as in the liver. Conversely, when eggs were injected into the portal veins of uninfected mice, anti-IL-4 treatment dramatically reduced the size of the resulting hepatic granulomas (Eltoum et al. 1995). It was clear that the site of the reaction, i.e. lung vs liver, was relatively unimportant. The state of host sensitization was also not of fundamental importance as granulomas around injected eggs were smaller after IL-4 treatment of both infected and uninfected mice. Instead the quality of the eggs seemed vital, i.e. eggs arriving in the tissues directly from the worms may be much more antigenic than eggs recovered from the livers of infected mice and then injected.

Although the lung model has been an extremely useful tool in the study of immune downregulation (Domingo \& Warren 1968), Souza Vidal et al. (1993) found that pulmonary granulomas in mice with portacaval shunts did not modulate while hepatic granulomas in the same mice downregulated in size.

Infection, of course, results in much more than merely the delivery of higher quality eggs to the tissues. Once the Th2 reaction has begun, IL-4 and IL-10 inhibit the production of IFN-g. This crossregulatory effect makes a switch in cytokine pat- 
terns particularly difficult. It is thus not surprising that treatment with anti-cytokine antibodies or with cytokines are much more easily demonstrated in the lung model than in infected mice (Table IV). However, the reverse effect is sometimes seen, i.e. mMT mice formed normal sized granulomas in the lung model (Epstein et al. 1995) but augmented granulomas in infected mice (Jankovic et al. 1998) and IL-10 KO mice formed small granulomas using the lung model (Wynn et al. 1997) but very large granulomas in the livers of 8 week infected mice (Wynn et al. 1998). This suggests a fundamental difference in immunoregulatory mechanisms although the questions of site versus egg injection or infection remain unanswered.

There are numerous reasons to think that intrinsic differences between the reactions of the liver and lung to $S$. mansoni eggs might exist. Miracidia in eggs injected into the tail vein are destroyed more rapidly than those injected into the portal vein (Feldman et al. 1990) and Leptak and McKerrow (1997) found a much more vigorous reaction to eggs injected into the lung than those injected into the liver. Other investigators have not noted a difference in the response to injected eggs at the two sites (Edungbola \& Schiller 1979, Raso et al. 1983, Eltoum et al. 1995) and the reasons for the discrepancy are not evident.

Relevance of murine infections for immunopathology in S. mansoni infected humans - The granulomas in mice and humans are similar histologi- cally and the factors regulating their formation and downmodulation are likely to be fundamentally similar. Judging from the apparent differences in granuloma regulation in different anatomic sites and in different mouse strains, our understanding of the process remains somewhat less than fundamental. This is not to say that the experimental findings are not useful for planning studies in humans and even for understanding human disease. In fact, the different responses of varied mouse strains to infection may all have relevance to the spectrum of human responses to schistosome infections. Different FcgR allotypes are known to be clinically important in human responses to infectious diseases (Deo et al. 1997).

We also lack a clear understanding of the relation of granuloma formation to the development of Symmers' portal fibrosis of the liver. One particularly bright spot on this horizon is the association of similar defects in regulatory idiotypes in Symmers' portal fibrosis in humans (Montesano et al. 1990) and mice (Henderson et al. 1993, Montesano et al. 1997). However, the connection between this idiotypic regulation of portal fibrosis and early or late downregulation of T cells, granuloma size or overall hepatic fibrosis is not evident. This association of deficient immunoregulation with disease leads one to believe that the continued elucidation of mechanisms of immune regulation in experimental animals and man is important.

TABLE IV

Comparison of granulomas in the lung model with those in infected mice

\begin{tabular}{llll}
\hline Treatment & $\begin{array}{l}\text { Lung } \\
\text { model }^{a}\end{array}$ & $\begin{array}{l}\text { Infection-Liver } \\
\text { Volume/Fibrosis }\end{array}$ & References \\
\hline Chronic infection & --- & $\begin{array}{l}\text { Liver ---/ ? } \\
\text { but lung granulomas } \\
\text { from shunted eggs } \\
\text { unaffected }\end{array}$ & $\begin{array}{l}\text { Warren et al. 1967, } \\
\text { Vidal Souza et al. 1993 }\end{array}$ \\
& & $++++/++++$ & Epstein et al. 1995, Jankovic et al. 1998 \\
mMT B cell ko & 0 & $-/---$ & Cheever et al. 1994, Eltoum et al. 1995 \\
Anti-IL-4 monoclonal & ---- & $0 / 0$ & Sher et al. 1990, Wynn et al. 1994 \\
Anti-IFN-g & ++ & $0 / 0$ & Wynn et al. 1994, Yap et al. 1997 \\
IFNg KO mouse & + & $\pm / \pm$ & Wynn et al. 1994, Oswald et al. \\
IL-12 & -- & & unpublished \\
IL-10 KO & -- & $0 / 0$ & Wynn et al. 1997, 1998 \\
CCRI ${ }^{b}$ KO & -- & Wynn et al. unpublished
\end{tabular}

$a$ : indicates a decrease; +: an increase; 0 : no change; $b$ : CC chemokine receptor 1. 


\section{REFERENCES}

Adewusi OI, Nix NA, Lu X, Colley DG, Secor WE 1996. Schistosoma mansoni: Relationship of tumor necrosis factor-a to morbidity and collagen deposition in chronic experimental infection. Exp Parasitol 84: 115-123.

Amiri P, Locksley RM, Parslow TG, Sadick M, Rector E, Ritter D, McKerrow JH 1992. Tumor necrosis factor a restores granulomas and induces parasite egg-laying in schistosome-infected SCID mice. $\mathrm{Na}$ ture 356: 604-607.

Andrade ZA, Warren KS 1964. Mild prolonged schistosomiasis in mice: alterations in host response with time and the development of portal fibrosis. Trans $R$ Soc Trop Med Hyg 58: 53-57.

Bosshardt SC, Freeman GL, Secor WE, Colley DG 1997. IL-10 deficit correlates with chronic hypersplenomegaly syndrome in male CBA/J mice infected with Schistosoma mansoni. Parasite Immunol 19: 347353.

Cheever AW 1997. Differential regulation of granuloma size and hepatic fibrosis in schistosome infections. Mem Inst Oswaldo Cruz 92: 689-692.

Cheever AW, Yap GS 1997. Immunologic basis of disease and disease regulation in schistosomiasis. Chem Immunol 66: 159-176.

Cheever AW, Byram JE, Hieny S, von Lichtenberg F, Lunde ML, Sher A 1985. Immunopathology of Schistosoma japonicum and S. mansoni infections in B cell depleted mice. Parasite Immunol 7: 399413.

Cheever AW, Finkelman FD, Caspar P, Heiny S, Macedonia JG, Sher A 1992. Treatment with anti-IL-2 antibodies reduces hepatic pathology and eosinophilia in Schistosoma mansoni-infected mice while selectively inhibiting T cell IL-5 production. J Immunol 148: 3244-3248.

Cheever AW, Lenzi JA, Lenzi HL, Andrade, ZA 1998. Experimental models of Schistosoma mansoni infection. In Rodrigo Correia Oliviera, Schistosomiasis, Ed. Oswaldo Cruz, in press.

Cheever AW, Williams ME, Wynn TA, Finkelman FD, Seder RA, Cox TM, Hieny S, Caspar P, Sher A 1994. Anti-interleukin-4 treatment of Schistosoma mansoni-infected mice inhibits development of $\mathrm{T}$ cells and non-B, non-T cells expressing Th2 cytokines while decreasing egg-induced hepatic fibrosis. J Immunol 153: 753-759.

Chensue SW, Boros DL 1979. Modulation of granulomatous hypersensitivity. I. Characterization of T lymphocytes involved in the adoptive suppression of granuloma formation in Schistosoma mansoni-infected mice. J Immunol 123: 1409-1414.

Chensue SW, Terebuh PD, Warmington KS, Hershey SD, Evanoff HL, Kunkel SL, Higashi GI 1992. Role of IL-4 and IFN-gin Schistosoma mansoni egg-induced granuloma formation. Orchestration, relative contribution, and relationship to macrophage function. J Immunol 148: 900-906.

Chensue SW, Warmington KS, Ruth J, Lincoln PM, Kunkel SL 1994a. Cross-regulatory role of interferon-gamma (IFN-g), IL-4 and IL-10 in schistosome egg granuloma formation: in vivo regulation of Th activity and inflammation. Clin Exp immunol 98: 395-400.

Chensue SW, Warmington KS, Ruth JR, Lincoln P, Kunkel SL 1995. Cytokine function during mycobacterial and schistosomal antigen-induced pulmonary granuloma formation. J Immunol 154: 59695976.

Chensue SW, Warmington K, Ruth J, Lincoln P, Kuo M-C, Kunkel SL 1994b. Cytokine responses during mycobacterial and schistosomal antigen-induced pulmonary granuloma formation. Am J Pathol 145: 1105-1113.

Chesney J, Metz C, Stavitsky AB, Bacher M, Bucala R 1998. Regulated production of type I collagen and inflammatory cytokines by peripheral blood fibrocytes. J Immunol 160: 419-425.

Colley DG 1976. Adoptive suppression of granuloma formation. $J$ Exp Med 143: 696-700.

Czaja MJ, Weiner FR, Takahashi S, Giambrone M-A, van der Meide PH, Schellekens H, Biempka L, Zern MA 1989. g-interferon treatment inhibits collagen deposition in murine schistosomiasis. Hepatology 10: 795-800.

Deo YM, Graziano RF, Repp R, Winkel JGJ van de 1997. Clinical significance of IgG Fc receptors and FcgRdirected immunotherapies. Immunol Today 18: 127 134.

Domingo EO, Warren KS 1968. Endogenous desensitization: changing host granulomatous response to schistosome eggs at different stages of infection with Schistosoma mansoni. Am J Pathol 52: 369-379.

Edungbola LD, Schiller EL 1979. Histopathology of hepatic and pulmonary granulomata experimentally induced with eggs of Schistosoma mansoni. J Parasitol 65: 253-261.

Eltoum IA, Wynn TA, Poindexter RW, Finkelman FD, Lewis FA, Sher A, Cheever AW 1995. Suppressive effect of IL-4 neutralization differs for granulomas around Schistosoma mansoni eggs injected into mice compared to eggs laid in infected mice. Infect Immun 69: 2532-2536.

Epstein MM, DiRosa, F, Jankovic D, Sher A, Matzinger P 1995. Successful T cell priming in B cell-deficient mice. J Exp Med 192: 915-922.

Feldman GM, Dannenberg AM Jr, Seed JL 1990. Physiologic oxygen tensions limit oxidant-mediated killing of schistosome eggs by inflammatory cells and isolated granulomas. J Leukocyte Biol 47: 344-354.

Flores-Villanueva PO, Zheng XX, Strom TB, Stadecker MJ 1996. Recombinant IL-10 and IL-10/Fc treatment down-regulate egg antigen-specific delayed hypersensitivity reactions and egg granuloma formation in schistosomiasis. J Immunol 156: 3315 3320.

Goes AM, Gazzinelli G, Rocha R, Katz N, Doughty BL 1991. Granulomatous hypersensitivity to Schistosoma mansoni egg antigens in human schistosomiasis. III. In vitro granuloma modulation induced by immune complexes. Am J Trop Med Hyg 4: 434443.

Green WF, Colley DG 1981. Modulation of Schistosoma 
mansoni egg-induced granuloma formation: I-J restriction of T cell mediated suppression in a chronic parasitic infection. Proc Natl Acad Sci USA 78: 11511156.

Henderson GS, Nix NA, Montesano MA, Gold D, Freeman GL, McCurley TL, Colley DG 1993. Two distinct pathologic syndromes in male $\mathrm{CBA} / \mathrm{J}$ inbred mice with chronic Schistosoma mansoni infections. Am J Pathol 142: 703-714.

Hernandez HJ, Wang Y, Stadecker MJ 1997a. In infection with Schistosoma mansoni, B cells are required for T helper type 2 cells responses but not for granuloma formation. J Immunol 158: 4832-4837.

Hernandez HJ, Wang Y, Tzellas N, Stadecker MJ 1997b. Expression of class II, but not class I, major histocompatibility complex molecules is required for granuloma formation in infection with Schistosoma mansoni. Eur J Immunol 27: 1170-1176.

Hood AT, Boros DL 1980. The effect of splenectomy on the pathophysiology and egg-specific immune response of Schistosoma mansoni-infected mice. Am J Trop Med Hyg 29: 586-591.

Jankovic D, Sher A 1996. Initiation and regulation of CD4+ T-cell function in host-parasite models. Chem Immunol 63: 51-65.

Jankovic D, Cheever AW, Kullberg MC, Wynn TA, Yap G, Caspar P, Lewis FA, Clynes R, Ravetch JV, Sher A 1998. CD4 ${ }^{+}$cell-mediated granulomatous pathology in schistosomiasis is downregulated by a B celldependent mechanism requiring Fc receptor signaling. J Exp Med 187: 619-629.

Jankovic D, Kullberg MC, Dombrowicz D, Barbieri S, Caspar P, Wynn TA, Paul WE, Cheever AW, Kinet J-P, Sher A 1997. FceRI-deficient mice infected with Schistosoma mansoni mount normal Th2-type responses while displaying enhanced liver pathology. J Immunol 159: 1868-1875.

Joseph AL, Boros DL 1993. Tumor necrosis factor plays a role in Schistosoma mansoni egg-induced granulomatous inflammation. J Immunol 151: 5461-5471.

Kresina TF, Olds GR 1986. Concomitant cellular and humoral expression of a regulatory cross-reactive idiotype in acute Schistosoma japonicum infection. Infect Immun 53: 90-94.

Leptak CL, McKerrow JH 1997. Schistosome egg granulomas and hepatic expression of TNF-a are dependent on immune priming during parasite maturation. J Immunol 158: 301-307.

Lukacs NW, Boros DL 1993. Lymphokine regulation of granuloma formation in murine schistosomiasis mansoni. Clin Immunol Immunopathol 68: 57-63.

Mathew RC, Ragheb S, Boros DL 1990. Recombinant IL-2 therapy-reverses diminished granulomatous responsiveness in anti-L3T4-treated Schistosoma mansoni-infected mice. J Immunol 144: 4356-4361.

Metwali A, Elliott D, Blum AM, Jie L, Sabdor M, Lynch R, Noben-Trauth N, Weinstock JV 1996. The granulomatous response in murine schistosomiasis mansoni does not switch to Th1 in IL-4-deficient C57BL/6 mice. J Immunol 157: 4546-4533.

Montesano MA, Freeman GL, Gazzinelli G, Colley DG 1990. Immune responses during human Schistosoma mansoni. XVII. Recognition by monoclonal antiidiotypic antibodies of several idiotypes on a monoclonal anti-soluble schistosomal egg antigen antibody and anti-soluble schistosomal egg antigen antibodies from patients with different clinical forms of infection. J Immunol 145: 3095-3099.

Montesano MA, Freeman GL, Secor WE, Colley DG 1997. Immunoregulatory idiotypes stimulate T helper 1 cytokine responses in experimental Schistosoma mansoni infections. J Immunol 158: 3800-3804.

Olds GR, Stavitsky AB 1986. Mechanisms of in vivo modulation of granulomatous inflammation in murine schistosomiasis japonicum. Infect Immun 52: 513-518.

Olds GR, Meneza S el, Mahmoud AAF, Kresina TF 1989. Differential immunoregulation of granulomatous inflammation, portal hypertension and hepatic fibrosis in murine schistosomiasis mansoni. $J$ Immunol 142: 3605-3611.

Pearce EJ, Cheever A, Leonard S, Covalesky M, Fernandez-Botran R, Kohler G, Kopf M 1996. Schistosomiasis in IL-4 deficient mice. Internat Immunol 8: 435-444.

Phillips SM, Ramadan MA, Zekavat AM, Hilliard B, Sugaya H el, Refaei M 1996. Regulation of the schistosome granuloma and fibrosis by TGFß-1 and antifibrotic chemotherapy-safronil. Am J Trop Med Hyg 55: abs no. 191.

Raso P, Mello RT de, Brasileiro Filho G, Rocha MO, Coelho PMZ 1983. Lesões hepáticas provocadas pela injeção de ovos de Schistosoma mansoni na veia porta de camundongos sensibilizados e não sensibilizados. Rev Inst Med Trop São Paulo 25: 236245.

Rezende SA, Lambertucci JR, Goes AM 1997a. Role of immune complexes from patients with different clinical forms of schistosomiasis in the modulation of in vitro granuloma reaction. Mem Inst Oswaldo Cruz. 92: 683-687.

Rezende SA, Silva Teixeira DN, Drummond SC, Goes AM 1997b. IL-10 plays a role in the modulation of human granulomatous hypersensitivity against Schistosoma mansoni eggs induced by immune-complexes. Scand J Immunol 46: 96-102.

Rosa Brunet L, Finkelman FD, Cheever AW, Kopf MA, Pearce EJ 1997. IL-4 protects against TNF-a mediated cachexia and death during acute schistosomiasis. J Immunol 159: 777-785.

Sher A, Coffman RL, Hieny S, Scott P, Cheever AW 1990. Interleukin 5 is required for the blood and tissue eosinophilia but not granuloma formation induced by infection with Schistosoma mansoni. Proc Nat Acad Sci USA 87: 61-65.

Souza Vidal MRF, Barbosa AA, Andrade ZA 1993. Experimental pulmonary schistosomiasis: lack of morphological evidence of modulation in schistosomal pulmonary granulomas. Rev Inst Med Trop São Paulo 33: 423-429.

Stadecker MJ 1992. The role of T-cell anergy in the immunomodulation of schistosomiasis. Parasitol Today 8: 199-204.

Villanueva POF, Reiser H, Stadecker MJ 1994. Regula- 
tion of $\mathrm{T}$ helper cell responses in experimental murine schistosomiasis by IL-10. J Immunol 153: 51905199.

Warren KS, Domingo EO, Cowan RBT 1967. Granuloma formation around schistosome eggs as a manifestation of delayed hypersensitivity. Am J Pathol 51: 735-756.

Weinstock JV 1992. Neuropeptides and the regulation of granulomatous inflammation. Clin Immunol Immunopathol 64: 17-22.

Weinstock JV, Boros DL 1981. Heterogeneity of the granulomatous response in the liver, colon, ileum, and ileal Peyer's patches to schistosome eggs in murine schistosomiasis mansoni. J Immunol 127: 1906-1909.

Weinstock JV, Chensue SW, Boros DV 1983. Modulation of granulomatous hypersensitivity. V. Participation of histamine receptor positive and negative lymphocytes in the granulomatous response of Schistosoma mansoni-infected mice. J Immunol 130: 423427.

Wynn TA, Cheever AW 1995. Cytokine regulation of granuloma formation in schistosomiasis. Curr Opin Immunol 7: 505-511.

Wynn TA, Cheever AW, Jankovic D, Poindexter RW, Caspar P, Lewis FA, Sher A 1995. An IL-12 based vaccination method for preventing fibrosis induced by schistosome infection. Nature 376: 594-596.

Wynn TA, Cheever AW, Williams ME, Hieny S, Caspar P, Kühn R, Müller W, Sher A, 1998. Interleukin-10 regulates liver pathology in acute murine schistosomiasis mansoni but is not required for immune downmodulation of chronic disease. J Immunol 160: 44734480.

Wynn TA, Eltoum I, Cheever AW, Lewis FA, Gause WC, Sher A 1993. Analysis of cytokine mRNA expression during primary granuloma formation induced by eggs of Schistosoma mansoni. J Immunol 151: 1430-1440.

Wynn TA, Eltoum I, Oswald IP, Cheever AW, Sher A 1994. Endogenous Interleukin 12 (IL-12) regulates granuloma formation induced by eggs of Schistosoma mansoni and exogenous IL-12 both inhibits and prophylactically immunizes against egg pathology. J Exp Med 179: 1551-1561.

Wynn TA, Morawetz R, Scharton-Kersten T, Hieny S, Morse HC III, Kuhn, R, Muller W, Cheever AW, Sher A 1997. Analysis of granuloma formation in double cytokine deficient mice reveals a central role for IL-10 in polarizing both th1 and th2-type cytokine responses in vivo. J Immunol 159: 5014-5023.

Yamashita T, Boros DL 1992. IL-4 influences IL-2 production and granulomatous inflammation in murine schistosomiasis mansoni. J Immunol 149: 3659 3664.

Yap G, Cheever A, Caspar P, Jankovic D, Sher A 1997. Unimpaired down-modulation of the hepatic granulomatous response in CD8T cell and IFN-gdeficient mice chronically infected with Schistosoma mansoni. Infect Immun 65: 2583-2586. 